\title{
Decreased Lead Levels, Kupang, and Boiling
}

${ }^{1}$ College student, Department of Public Health, Health Faculty, Gresik Muhammadiyah University, Indonesia

${ }^{2}$ Lecturer Department of Public Health, Health Faculty, Gresik Muhammadiyah University, Indonesia

\section{Article Info}

Article history:

Received Jun 9, 2019

Revised Nov 20, 2019

Accepted Feb 11, 2020

\section{Keywords:}

Decreased Lead Levels

Kupang

Boiling

\begin{abstract}
Lead is one of the very dangerous heavy metals that can pollute the environment. Sidoarjo Regency is an industrial area in East Java which has several factories, some of which do not process industrial waste properly. This untreated waste is made directly into the water so that it pollutes the water so that it serves the biota in the water, one of which is mussel. This research aims to determine the effect of boiling in an effort to reduce lead levels in Kupang. This research was conducted by taking samples of Kupang in Balongdowo village, Candi Sidoarjo District.
\end{abstract}

This research was included in an experiment to reduce mercury content with boiling time of 15 minutes, 30 minutes, 45 minutes and 60 minutes. The analyzed results are presented in tabular and graphical form. The results showed a decrease in lead levels at a boiling time of 30 minutes by $0.8886 \mathrm{mg} / \mathrm{L}$ with the difference reaching a decrease of 0.211 and a boiling time of 45 minutes can decrease by $0,8211 \mathrm{mg} / \mathrm{L}$ with a difference of a decrease of 0.0675 . This means that there is an effect of boiling in an effort to reduce lead levels in Kupang.

Copyright () 2020 University Muhammadiyah of Gresik. All rights reserved.

\section{Corresponding Author:}

\section{Dwy Retno Juniawanti,}

College student, Department of Public Health, Health Faculty,

Gresik Muhammadiyah University,

Street Sumatera 101 Gresik Kota Baru (GKB), Gresik - 61121.

Email: retno.sda.72@gmail.com 


\section{INTRODUCTION}

The development of an increasingly increasing industry, has positive and negative impacts. The positive impact of increasing industrial development is that it can open many jobs for local people and can increase regional income [1].

According to the research of [2] pollutants entering the river mouth will spread and settle, resulting in the spread of pollutants that can cause pollution in water. Very dangerous heavy metals that can pollute the environment are cadmium $(\mathrm{Cd})$, mercury $(\mathrm{Hg})$ and lead $(\mathrm{Pb})$, which are the result of industrial waste discharges which have now spread in the Java Sea. As a result of pollution, fish, shellfish and other biota in the sea are not suitable for consumption.

Sidoarjo Regency is an industrial area other than in Surabaya and Gresik which has many factories operating in its area, so a lot of waste is generated. Not a few of these factories process their waste well. Lots of waste disposal directly into the waters to pollute the waters so that endangering the biota in the waters [3].

According to [4] which contributes to large pollution in the city of Surabaya is the river estuary from Brantas, along the river flow filled with a variety of industries, settlements, kenjeran beach areas and other beaches such as the beach near the river estuary ketingan Balongdowo Village Sidoarjo Temple vulnerable to the impact of waste factory waste and household waste in the urban area of Sidoarjo Regency.

Kupang lontong is a typical food of Sidoarjo Regency which is taken from the waters in Sidoarjo. Kupang, which is also a type of shellfish, consumes plankton and seawater. The condition of the waters in Sidoarjo is likely to occur due to heavy metal pollution due to factory waste discharges into the river, resulting in pollution of the biota in it, especially in Kupang. Kupang has been contaminated with heavy metals such as lead which can potentially endanger the health of its consumers, this is because the cooking process cannot completely eliminate lead content in the body of living things even though it has been processed through a process of heating and boiling [5].

White Kupang has a lateral convex shape and has a shell with two halves and dorsal hinges covering the entire body. Kupang has the shape of the foot like other body parts namely lateral convex so that it is called pelecypoda ax feet. The difference of white mussel has no bysus, which is a style that functions attached to the substrate, has a siphon with a clearly visible shape, the shell closes with the edge still slightly open and its shape slightly oval [6].

Based on a preliminary study of the results of interviews of 10 (ten) on kupang lontong sellers for initial processing, especially in boiling mussels it is known that the average length of boiling is $\pm 11 / 2$ hours ( 90 minutes) before the seasoning process in the mussels. According to the results of Athifah, et al () boiling mussel meat with acid type and the difference in concentration significantly affected $\mathrm{Pb}$ levels and $\mathrm{pH}$ values. This means that there are still levels of $\mathrm{Pb}$ in Kupang to be consumed, so the cooking process greatly influences the decrease in $\mathrm{Pb}$ levels. The above problems can be done research about "The Effect of Long Boiling in an Effort to Reduce PB levels in Kupang".

\section{RESEARCH METHOD}

This type of experimental analytic research with quasi-experimental method (Quasi Experiment). This study analyzes the effect of boiling time in an effort to reduce lead levels $(\mathrm{Pb})$ in Kupang in Sidoarjo Regency 
The design of the Equivalent Time Series Samples Design is almost the same as the time series design, the difference is that the treatment is not only introduced not once, but repeatedly interspersed with periods of no treatment.

Population is a group of individuals who live in the same area, or a group of individuals or objects that have the same or uniform characteristics [7].

The population of this study is the white mussel which is also called the rice mussel living settled in the muddy or sandy waters and the largest concentration is in the river mouth.

The sample is a small fraction of the population used in research to obtain statistical information about the entire population. The sample is a miniature of the population [8]. This sample consists of fresh white mussel samples and shells taken from the Balongdowo village, Candi District, Sidoarjo Regency.

\section{RESULTS AND DISCUSSIONS}

This research uses kupang meat from Balongdowo Village, Sidoarjo Temple District. Samples taken from the sea are washed thoroughly, then boiled for 15 minutes, 30 minutes, 45 minutes and 60 minutes, then determined the lead content $(\mathrm{Pb})$ after inspection to the Laboratory and the percentage reduction is calculated.

Sidoarjo Regency is an industrial area other than in Surabaya and Gresik which has many factories operating in its area, so a lot of waste is generated. Not a few of these factories process their waste well. Lots of waste disposal directly into the waters to pollute the waters so that endangering the biota in the waters. According to the research of [7] pollutants entering the river mouth will spread and experience sedimentation, resulting in the spread of pollutants that can cause pollution in water. One of them is metal-based metal pollution. As a result of pollution, fish, shellfish and other biota in the sea are not suitable for consumption. In this research, treatment was carried out

The results of the data reduction in lead levels in Kupang has not yet gone through the boiling process and after going through the boiling process

\section{. Table 1}

Data on lead reduction in mussels not yet through the boiling process and after the boiling process

$\begin{array}{clllc}\text { No } & \text { Boiling Time (minutes) } & \text { Lead Content }(\mathbf{m g} / \mathbf{k g}) & \text { Decrease }(\mathbf{m g} / \mathbf{k g}) & \boldsymbol{\%} \\ 1 & 0 & 1,6441 & 0 & \\ 2 & 15 & 1,5201 & 0,124 & 12 \% \\ 3 & 30 & 0,8886 & 0,756 & 76 \% \\ 4 & 45 & 0,8211 & 0,823 & 83 \% \\ 5 & 60 & \leq \mathrm{LD}(<0,8100) & >0,834 & >83 \%\end{array}$

Lead content $(\mathrm{Pb})$ in Kupang is below the minimum limit in accordance with SNI at 30 minutes boiling time. The longer the steamed meat is done by boiling, the lead content $(\mathrm{Pb})$ will decrease. Even when steamed meat is boiled for 60 minutes, lead $(\mathrm{Pb})$ levels are not detected because the result is $\leq \mathrm{LD} \mathrm{mg} / \mathrm{Kg}$. The detection limit (LD) is 0.8100 according to SNI standards.

Decrease lead levels in Kupang with boiling time for 15 minutes, 30 minutes, 45 minutes, 60 minutes. The results of the reduction can be seen in Figure 2 : 


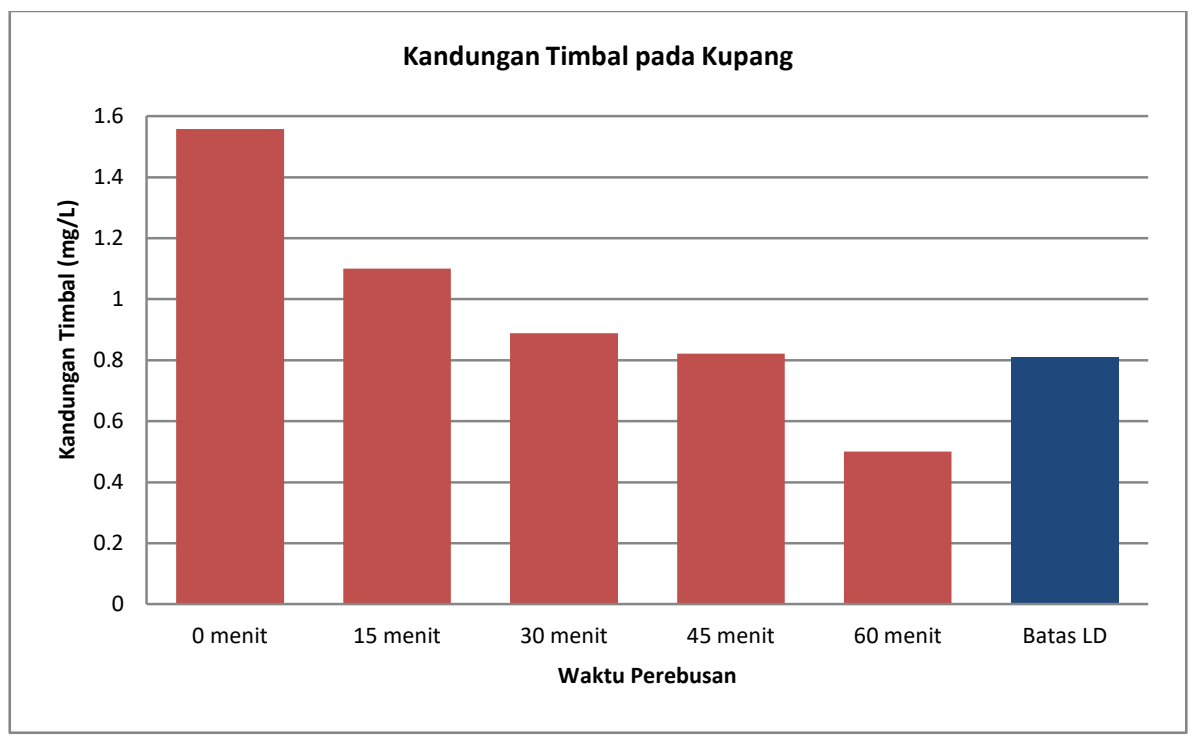

The lead levels decreased $(\mathrm{Pb})$ in Kupang. In the first process without boiling the lead content was $1.6441 \mathrm{mg} / \mathrm{kg}$. Then boiling for 15 minutes lead levels decreased to $1.5201 \mathrm{mg} / \mathrm{kg}$ with a difference of a decrease of 0.124 . The next boiling that is for 30 minutes can reduce lead levels to $0.8886 \mathrm{mg} / \mathrm{kg}$ with the difference reaching $0.756 \mathrm{mg}$ $/ \mathrm{kg}$. The third boil that is for 45 minutes can reduce by $0,8211 \mathrm{mg} / \mathrm{kg}$ with a difference of a decrease of $0.823 \mathrm{mg} / \mathrm{kg}$. Boiling for 60 minutes was not detected $\leq \mathrm{LD}$ per $\mathrm{mg} / \mathrm{kg}$. The detection limit (LD) is 0.8100 . Difference in reduction is estimated > $0.834 \mathrm{mg} / \mathrm{kg}$. It can be seen that optimal boiling at boiling time is 30 minutes and 45 minutes, while boiling time of 60 minutes is less than optimal based on laboratory results.

\section{CONCLUSION}

The conclusions obtained from this study are:

a. Lead content in mussels without going through the boiling process was $1,6441 \mathrm{mg} /$ $\mathrm{kg}$.

b. The longer the boiling is done, the greater the reduction in lead levels in Kupang.

c. Lead levels decreased at a time of boiling 30 minutes by $0.8886 \mathrm{mg} / \mathrm{kg}$ with a difference of a decrease of 0.6315 and boiling time of 45 minutes can reduce by 0 , $8211 \mathrm{mg} / \mathrm{kg}$ with a difference of a decrease of 0.0675 .

d. Boiling for 60 minutes was not detected $\leq$ LD per $\mathrm{mg} / \mathrm{kg}$. The detection limit (LD) is 0.8100 .

\section{SUGGESTION}

Suggestions obtained from this study are:

a. The longer the boiling is done it will reduce the lead levels in the mussel and also reduce the nutritional content in the mussel.

b. Further research is needed regarding the reduction of nutritional content in mussel.

\section{REFERENCES}

[1] Ardyanto, D., 2005. Detection of Black Tin Pollution (PB) in the Blood of LeadExposed Communities (Plumbum). Journal of Environmental Health, Vol. 2 No.1, Page: 67-76. Surabaya: Airlangga University. 
[2] ATSDR. 1999. Preliminary Study of the Development of Kupang as a Cheap and Nutritious Food. Jakarta: PN Bali Reader

[3] Bose-Oreily, S., McCarty, K.M., Steckling, N. \& Lettmeier, B., 2010. Mercury Exposure anda Children Health. Current Problem in Pediatric and Adolescen Helath Care, Volume 8, p.40.

[4] BSNI, 2009. SNI 7387; 2009 Maximum Limits of Heavy Metal Contamination in Food

[5] Burger, J. \& Gochfeld, M., 2012. Mercury and Public Health : An Assesment of Human. In : M.S. Bank, ed. Mercury in Environment. London: University of California Press.

[6] Izza, Athifah T, et.al., Decreased Lead Content $(\mathrm{Pb})$ in Red Kupang (Musculitas senhausia) with Boiling Acid in the Study of Acid Type and Concentration. Malang: Brawijaya University.

[7] Lasorsa, B.K., Gill, G.A. \& Horvat, M., 2012. Analytical Methods for Measuring Mercury in Water, Sediment and Biota. In : Mercury in the Environment: Pattern and Process. Los Angeles: University of California Press, pp.27-54.

[8] Lippmann, M., 2000. Environment Toxicant: Human Exposure and Their Health Effect. 2nd ed. Kanada: A John Willey and Sons Inc.

[9] Lou, H-W.et al., 2016. Photochemical Reaction Between Mercury (Hg) and dissolved Organic Matter Decrease $\mathrm{Hg}$ Bioavaiability and Methylation. Environmental Pollution, pp.1-7.

[10]Rachmawati, et.al. 2013. The Effect of Long Boiling of Blood Clams (Anadara granosa) with Active Charcoal Against Reduction of Cadmium Metal Levels and Lead Metal Levels. Journal of Aquatic Product Processing and Biotechnology. Vol 2, No. 2 , pp. 41-50. 